\title{
Study of Oncoprotein 24p3 as Diagnostic Marker for Hepatocellular Carcinoma on Top of Hepatitis C Virus
}

\author{
Sara M. Abd Elaziz ${ }^{(1)}$, Amany M. Abo Elenein ${ }^{(1)}$, Dina H. Ziadh ${ }^{(2)}$, Sara A. Hamam ${ }^{(1)}$, Sara M. A \\ ${ }^{(1)}$ Department of Clinical Pathology and ${ }^{(2)}$ Department of Tropical Medicine, \\ Faculty of Medicine, Tanta University, Egypt \\ Corresponding author: Sara M. Abd Elaziz; Email: saraabdlaziz11@gmail.com
}

\begin{abstract}
Background: Hepatitis $\mathrm{C}$ virus is one of the main causes of chronic liver disease worldwide. Egypt has the highest prevalence of HCV in the world, estimated nationally at $14.7 \%$ and is therefore confronted with a disease burden of historical proportions that distinguishes this nation from others. In HCC, 24P3 is overexpressed in tissues and closely associated with the proliferation and invasion of HCC cells.24P3 is mainly expressed in myeloid cells and later assigned to a cluster of at least three lipocalins on the long arm of human chromosome 9.

Aim of the Work: was to shed the light on the role of oncoprotein $24 \mathrm{p} 3$ as a diagnostic marker in patients with hepatocellular carcinoma complicating hepatitis $\mathrm{C}$ virus.

Subjects and Methods: This case control clinical study was carried out on 60 subjects who were divided into three groups: Group I: Twenty Patients diagnosed with HCC on top of HCV. Group II: Twenty Patients diagnosed with HCV without HCC. Group III: Twenty normal subjects with matched age and sex as a control group. Studied groups were subjected to abdominal ultrasonography, triphasic CT for patients with focal lesions, laboratory investigations including; liver function tests included hepatitis markers and serum 24P3, detected by enzyme linked immunosorbent assay (ELISA).

Results: The study revealed a significant increase in AFP in Group I compared to Group II and in Group II compared to Group III. A significant difference $\mathrm{P}=0.001$ was found among the three different groups. The cutoff for AFP was $>20 \mathrm{ng} / \mathrm{mL}$, sensitivity was $70 \%$, specificity was $85 \%$, PPV $90 \%$, NPV $65 \%$ and accuracy $78 \%$. There was a significant increase of 24P3 in Group I compared to Group II and in Group II compared to Group III. A statistical significance $\mathrm{p}=0.001$ was found among the three different groups. The cutoff for $24 \mathrm{P} 3$ was $>250 \mathrm{ng} / \mathrm{mL}$ and its sensitivity, specificity, PPV, NPV, and accuracy were all $100 \%$. Based on the present study, 24P3 has a higher sensitivity, specificity and accuracy as compared to AFP, a famously used biomarker in HCC. Conclusion: Serum 24P3 levels in patients with HCV may be used as a guide for progression and prognosis of HCC. In these patients, if 24P3 levels were found to be high, serum alpha- feto protein and ultrasonographic examination could be repeated at more frequent intervals. This may also be used as a guide in terms of the treatment plan. Measurement of 24P3 in sera of large number of patients and follow up may pave the way to pick up early stage of HCC and showed its prognostic effect.
\end{abstract}

Keywords: oncoprotein 24P3, hepatocellular carcinoma, hepatitis C virus.

\section{INTRODUCTION}

Cancer is among the leading causes of morbidity and mortality worldwide, accounting for 14 million cases and 8.2 million deaths in 2012. Globally, liver cancer is the fifth most common type of cancer and third most common cause of cancer mortality. In the United States (US), according to the Surveillance, Epidemiology, and End Results Program (SEER) estimates in 2015, liver cancer accounted for $2.2 \%$ of all new cancer cases and $4.2 \%$ of all cancer deaths; hepatocellular carcinoma (HCC) is the most common primary liver cancer, accounting for nearly $80 \%$ of all primary liver cancers ${ }^{(1)}$.

Although HCC has been examined extensively and although its symptoms are well known, its early diagnosis remains difficult; thus, the survival rate after diagnosis is low $(<10 \%)$. The conventional diagnostic tools include alpha feto protein (AFP), liver biopsy, and radiographic imaging. As aless invasive and cost-effective procedure, a blood test can be used to measure $\mathrm{AFP}^{(2)}$.

Among serological biomarkers, AFP is the approved marker for screening HCC, but it is not used routinely by clinicians, due to its insufficient sensitivity and specificity. To improve the diagnosis and prognosis of HCC, additional reliable markers must be identified that can be used for its early and accurate detection ${ }^{(2)}$.

$24 \mathrm{P} 3$, belongs to the lipocalin family that were first proposed to have unifying functions in the transport of hydrophobic substances. It was initially isolated and purified as $25-\mathrm{kD}$ a neutrophil protein that is inpart associated with gelatinase from human neutrophils ${ }^{(\mathbf{3})}$.

24P3 is mainly expressed in myeloid cells and later assigned to a cluster of at least three lipocalins on the long arm of human chromosome $9^{(3)}$. It starts being expressed in the embryonic stage and it has been shown to be activated strongly in inflamed 
organs such as liver, heart, lungs, bone marrow, kidney, and spleen ${ }^{(4)}$.

Moreover, it seems to participate in carcinogenesis by favoring iron uptake from extra cellular spaces with in malignant cells, a fundamental process for maintaining neoplastic cell multiplication $^{(5)}$.

24P3 synthesis is induced by factors promoting the development of qualification neoplasias and its over expression was found in several malignancies including breast, gastric, esophageal, squamous cell, colorectal, pancreatic, lung, and ovarian cancers ${ }^{(\boldsymbol{(})}$. It binds to metalloproteinase 9 (MMP-9), which secreted by tumor cells and enhance tumor invasiveness and metastasis and forms aMMP-9/24P3 complex, preventing the degradation of MMP-9 ${ }^{(7)}$.

The aim of this study was to shed the light on the role of oncoprotein $24 \mathrm{p} 3$ as a diagnostic marker in patients with hepatocellular carcinoma complicating hepatitis c virus.

\section{SUBJECTS AND METHODS}

This case control clinical study included a total of 60 subjects attending at Tropical Medicine Department, Tanta University Hospitals.

\section{Approval of the ethical committee and a} written informed consent from all the subjects were obtained. This study was conducted during 2017. The sixty subjects were divided into three groups:

- Group I: Twenty Patients diagnosed with HCC on top of HCV.

- Group II: Twenty Patients diagnosed with HCV without HCC.

- Group III: Twenty normal subjects with matched age and sex as a control group.

\section{Inclusion Criteria:}

Patients with age range 40-70 years, diagnosed with $\mathrm{HCC}$ on top of $\mathrm{HCV}$ and patients diagnosed with $\mathrm{HCV}$ without HCC.

Exclusion Criteria:

Patients who underwent surgical intervention for HCC, patients who started therapeutic regimen for $\mathrm{HCV}$ and patients with HCC on top of HBV.

Studied groups were subjected to the following parameters:

1- Full history taking and thorough clinical examination.

2- Abdominal ultrasonography.

3- Triphasic CT for patients with focal lesions.

4- Laboratory investigations including:

a) Liver function tests include:

- ALT

- AST

- Albumin

- Total Bilirubin
- Direct Bilirubin

- Prothrombin time.

b) Complete blood count.

c) Serum AFP level.

d) Hepatitis markers. enzyme linked immuno sorbent assay(ELISA).

e) Hepatitis C virus RNA.

f) Serum 24P3, detected by

\section{RESULTS}

This study was carried out on 60 subjects divided into 3 groups as follow:

- Group I: 20 patients (14 males and 6 females).

- Group II: 20 patients (4 males and 16 females).

- Group III: 20 subjects (11 males and 9 females).

II) Laboratory data:

In group I, $\mathrm{Hb}$ mean was $(9.25 \pm 1.91 \mathrm{~g} / \mathrm{dL})$. In group II it was $(12.35 \pm 1.91 \mathrm{~g} / \mathrm{dL})$ and in group III it was $(13.45 \pm 2.05 \mathrm{~g} / \mathrm{dL})$.

There was astatistical significant difference in $\mathrm{Hb}$ among the three groups $(\mathbf{P}<\mathbf{0 . 0 0 1})$. Hb was significantly lower in group I as compared to group II $(\mathbf{P}<\mathbf{0 . 0 0 1})$ and group III $(\mathbf{P}=\mathbf{0 . 0 0 1})$. No significant difference could be detected between groups II\&III $(\mathbf{P}=\mathbf{0 . 1 2 4})$.

Table (1): Comparison between mean values of $\mathrm{Hb}$ (g/dL) among the studied groups.

\begin{tabular}{|c|ccc|c|c|}
\hline \multirow{2}{*}{ Groups } & \multicolumn{3}{|c|}{ Hb $(\mathbf{g m} / \mathbf{d L})$} & \multicolumn{2}{c|}{ ANOVA } \\
\cline { 2 - 4 } & Mean & $\mathbf{1}$ & SD & F & P-value \\
\hline GroupI & 9.25 & \pm & 1.909 & & \\
\hline GroupII & 12.35 & \pm & 1.909 & \multirow{2}{*}{15.709} & $<0.001 *$ \\
\hline GroupIII & 13.45 & \pm & 2.051 & & \\
\hline \multicolumn{5}{|c|}{ TUKEY'STest } & II\&III \\
\hline I\&II & \multicolumn{3}{|c|}{ I\&III } & 0.124 \\
\hline <0.001* & \multicolumn{3}{|c|}{$001^{*}$} & mean was
\end{tabular}

$\left(70 \pm 28.28 \times 10^{3} / \mathrm{mm}^{3}\right)$. In group II it was $\left(106.5 \pm 40.3 \times 10^{3} / \mathrm{mm}^{3}\right)$ and in group III It was $\left(275 \pm 148.5 \times 10^{3} / \mathrm{mm}^{3}\right)$.

There was astatistical significant difference in platelets count among the three groups $(\mathbf{P}=\mathbf{0 . 0 0 3})$. Platelets count was significantly lower in group I as compared to group II $(\mathbf{P}=\mathbf{0 . 0 0 2})$ and group III $(\mathbf{P}=\mathbf{0 . 0 0 1})$. No significant difference could be

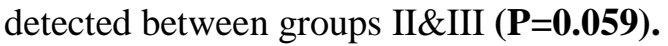

Table (2): Comparison between mean values of platelet count $\left(\times 10^{3} / \mathrm{mm}^{3}\right)$ among the studied groups.

\begin{tabular}{|c|ccc|c|c|}
\hline \multirow{2}{*}{ Groups } & \multicolumn{3}{|c|}{ Platelets $\left(\times \mathbf{1 0}^{\mathbf{3}} / \mathbf{m m}^{\mathbf{3}}\right)$} & \multicolumn{2}{c|}{ ANOVA } \\
\cline { 2 - 4 } & Mean & $\mathbf{\pm}$ & $\mathbf{S D}$ & $\mathbf{F}$ & P-value \\
\hline Group I & 70 & \pm & 8.284 & & \\
\hline Group II & 106.5 & \pm & 4.305 & \multirow{2}{*}{6.517} & $0.003^{*}$ \\
\hline Group III & 275 & \pm & 18.49 & & \\
\hline \multicolumn{5}{|c|}{ TUKEY'S Test } \\
\hline I\&II & \multicolumn{3}{|c|}{ I\&III } & II\&III \\
\hline $0.002 *$ & & $0.001 *$ & 0.059 \\
\hline
\end{tabular}


In group I albumin mean was $(2.8 \pm 0.283 \mathrm{~g} / \mathrm{dL})$, while in group II it was $(3.45 \pm 0.777 \mathrm{~g} / \mathrm{dL})$, and in group III it was $(4.3 \pm 0.849 \mathrm{~g} / \mathrm{dL})$.

There was astatistical significant difference in albumin levels among the three groups $(\mathbf{P}<\mathbf{0 . 0 0 1})$. Serum albumin level was significantly lower in group I as compared to group II $(\mathbf{P}<\mathbf{0 . 0 0 1})$ and group III $(\mathbf{P}<\mathbf{0 . 0 0 1})$ and in group II as compared to group III $(\mathbf{P}=\mathbf{0 . 0 0 3})$.

Table (3): Comparison between mean values of albumin (gm/dL) among the studied groups.

\begin{tabular}{|c|c|c|c|c|c|}
\hline \multirow[b]{2}{*}{ Groups } & \multicolumn{3}{|c|}{$\operatorname{Albumin}(\mathrm{gm} / \mathrm{dL})$} & \multicolumn{2}{|c|}{ ANOVA } \\
\hline & Mean & \pm & SD & $\mathbf{F}$ & $\begin{array}{c}\text { P- } \\
\text { value }\end{array}$ \\
\hline Group I & 2.8 & \pm & 0.283 & \multirow{3}{*}{$\begin{array}{c}16.01 \\
0\end{array}$} & \multirow{3}{*}{$\begin{array}{c}<0.001 \\
*\end{array}$} \\
\hline Group II & 3.45 & \pm & 0.777 & & \\
\hline $\begin{array}{c}\text { Group } \\
\text { III }\end{array}$ & 4.3 & \pm & 0.849 & & \\
\hline \multicolumn{6}{|c|}{ TUKEY'S Test } \\
\hline \multicolumn{2}{|c|}{ I\&II } & \multicolumn{3}{|c|}{ I\&III } & II\&III \\
\hline \multicolumn{2}{|c|}{$<0.001 *$} & \multicolumn{3}{|c|}{$<0.001 *$} & $0.003 *$ \\
\hline
\end{tabular}

Total Bilirubin mean in group I was $(8.6 \pm 1.98 \mathrm{mg} / \mathrm{dL})$, while in group II it was $(3.76 \pm 1.64 \mathrm{mg} / \mathrm{dL})$ and in group III it was $(0.8 \pm 0.42 \mathrm{mg} / \mathrm{dL})$.

There was a statistical significant difference in Total Bilirubin among the three groups $(\mathbf{P}=\mathbf{0 . 0 0 3})$. Total Bilirubin was significantly higher in group I as compared to group II $(\mathbf{P}=\mathbf{0 . 0 0 2})$ and group III $(\mathbf{P}=\mathbf{0 . 0 0 7})$ and in groups II as compared to group III $(\mathbf{P}=\mathbf{0 . 0 0 1})$.

Table (4): comparison of the Total Bilirubin levels $(\mathrm{mg} / \mathrm{dL})$ among studied groups.

\begin{tabular}{|c|c|c|c|c|c|}
\hline \multirow{2}{*}{ Groups } & \multicolumn{3}{|c|}{ Total Bilirubin $(m g / d L)$} & \multicolumn{2}{|c|}{ ANOVA } \\
\hline & Mean & \pm & SD & $\mathbf{F}$ & P-value \\
\hline Group I & 8.6 & \pm & 1.979 & \multirow{3}{*}{6.408} & \multirow{3}{*}{$0.003 *$} \\
\hline Group II & 3.76 & \pm & 1.64 & & \\
\hline Group III & 0.8 & \pm & 0.024 & & \\
\hline \multicolumn{6}{|c|}{ TUKEY'S Test } \\
\hline \multicolumn{2}{|c|}{ I\&II } & \multicolumn{3}{|c|}{ I\&III } & II\&III \\
\hline \multicolumn{2}{|c|}{$0.002 *$} & \multicolumn{3}{|c|}{$0.007 *$} & $0.001 *$ \\
\hline \multicolumn{2}{|c|}{$\begin{array}{c}\text { In group } \\
(23.45 \pm 5.02 \mathrm{sec} .) \\
(15.75 \pm 4.737 \mathrm{sec} .)\end{array}$} & \multicolumn{4}{|c|}{ I prothrombin mean was } \\
\hline
\end{tabular}

There was a statistical significant difference in PT between the three groups $(\mathbf{P}=\mathbf{0 . 0 0 1})$.

PT was significantly higher in group I as compared to group II ( $\mathbf{P = \mathbf { 0 . 0 0 1 }})$ and group III $(\mathbf{P}=\mathbf{0 . 0 0 1})$ and in group II as compared to group III $(\mathbf{P}=\mathbf{0 . 0 0 3})$.
Table (5): Comparison between mean values of PT (seconds) among the studied groups.

\begin{tabular}{|c|c|c|c|c|c|}
\hline \multirow{2}{*}{ Groups } & \multicolumn{3}{|c|}{ Prothrombin(sec.) } & \multicolumn{2}{|c|}{ ANOVA } \\
\hline & Mean & \pm & SD & $\mathbf{F}$ & P-value \\
\hline Group I & 23.45 & \pm & 5.02 & \multirow{3}{*}{5.236} & \multirow{3}{*}{$0.001 *$} \\
\hline Group II & 15.75 & \pm & 3.737 & & \\
\hline Group III & 12.5 & \pm & 1.414 & & \\
\hline \multicolumn{6}{|c|}{ TUKEY'S Test } \\
\hline \multicolumn{2}{|c|}{ I\&II } & \multicolumn{3}{|c|}{ I\&III } & II\&III \\
\hline \multicolumn{2}{|c|}{$0.001 *$} & \multicolumn{3}{|c|}{$0.001 *$} & $\begin{array}{c}0.003 \\
*\end{array}$ \\
\hline
\end{tabular}

In group I AFP median was (1715IU/mL) and mean rank was $(64.90 \mathrm{IU} / \mathrm{mL})$. In group II, AFP median was $(123.8 \mathrm{IU} / \mathrm{mL})$ and mean rank was (34.87IU/mL). In group III AFP median was $(2.7 \mathrm{IU} / \mathrm{mL})$ and mean rank was $(12.35 \mathrm{IU} / \mathrm{mL})$.

There was statistical significant difference in AFP among the three groups $(\mathbf{P}=\mathbf{0 . 0 9 2})$. AFP was significantly higher in group I as compared to group II $(\mathbf{P}<\mathbf{0 . 0 0 1})$ and group III $(\mathbf{P}<\mathbf{0 . 0 0 1})$ and in group II as compared to group III $(\boldsymbol{P}=\mathbf{0 . 0 0 6})$.

Table (6): Comparison between median values of AFP (U/L) among the studied groups.

\begin{tabular}{|c|c|c|c|c|c|}
\hline \multirow{2}{*}{ Groups } & \multicolumn{3}{|c|}{$\operatorname{AFP}(I U / L)$} & \multicolumn{2}{|c|}{$\begin{array}{c}\text { Kruskal-Wallis } \\
\text { Test }\end{array}$} \\
\hline & Median & $\begin{array}{l}\text { Mean } \\
\pm \text { SD }\end{array}$ & \begin{tabular}{|l|} 
Mean \\
Rank
\end{tabular} & $\mathbf{X}^{2}$ & P-value \\
\hline Group I & 715 & $\begin{array}{c}1715 \pm \\
49.8\end{array}$ & 64.90 & \multirow{3}{*}{64.194} & \multirow{3}{*}{$0.092 *$} \\
\hline Group II & 23.75 & $\begin{array}{c}123.75 \pm \\
14.30\end{array}$ & 34.87 & & \\
\hline \begin{tabular}{|c|} 
Group \\
III
\end{tabular} & .7 & $\begin{array}{c}2.7 \pm \\
0.5355\end{array}$ & 12.35 & & \\
\hline \multicolumn{6}{|c|}{ Mann-Whitney Test } \\
\hline \multicolumn{2}{|c|}{ I\&II } & I\&III & & \multicolumn{2}{|c|}{ II\&III } \\
\hline \multicolumn{2}{|c|}{$<0.001 *$} & $<0.001^{*}$ & & \multicolumn{2}{|c|}{0.006} \\
\hline
\end{tabular}

In group I $24 \mathrm{P} 3$ median was $(424.85 \mathrm{ng} / \mathrm{mL})$ and mean rank was $(65.50 \mathrm{ng} / \mathrm{mL})$. In group II $24 \mathrm{P} 3$ median was $(166.86 \mathrm{ng} / \mathrm{mL})$ and mean rank was $(35.50 \mathrm{ng} / \mathrm{mL})$. In group III $24 \mathrm{P} 3$ ranged from median was $(47.69 \mathrm{ng} / \mathrm{mL})$ and mean rank was (10.50ng/mL).

There was statistical significant difference in 24P3 levels among the three groups $(\mathbf{P}<\mathbf{0 . 0 0 1}) .24 \mathrm{P} 3$ levels was significantly higher in group $\mathrm{I}$ as compared to group II $(\mathbf{P}<\mathbf{0 . 0 0 1})$ and group III $(\mathbf{P}<\mathbf{0 . 0 0 1})$ and in group II as compared to group III $(\mathbf{P}<0.001)$. 
Table (7): Comparison between median values $24 \mathrm{P} 3(\mathrm{ng} / \mathrm{mL})$ in the studied groups

\begin{tabular}{|c|c|c|c|c|c|}
\hline \multirow[b]{2}{*}{$\begin{array}{c}\text { Group } \\
\mathbf{s}\end{array}$} & \multicolumn{3}{|c|}{$24 \mathrm{P3}(n g / m L)$} & \multicolumn{2}{|c|}{$\begin{array}{c}\text { Kruskal-Wallis } \\
\text { Test }\end{array}$} \\
\hline & Median & Mean \pm SD & $\begin{array}{l}\text { Mea } \\
\text { n } \\
\text { Ran } \\
\text { k }\end{array}$ & $\mathrm{X}^{2}$ & $\begin{array}{l}P \text { - } \\
\text { value }\end{array}$ \\
\hline \begin{tabular}{|c|} 
Group \\
I
\end{tabular} & 424.85 & $422.797 \pm 8.011$ & 65.5 & 69.446 & $\begin{array}{l}<0.001 \\
* \\
\end{array}$ \\
\hline \begin{tabular}{|c|} 
Group \\
II
\end{tabular} & 166.85 & $159.537 \pm 16.00$ & 35.5 & & \\
\hline \begin{tabular}{|c|} 
Group \\
III
\end{tabular} & 47.69 & $47.198 \pm 4.322$ & 10.5 & & \\
\hline \multicolumn{6}{|c|}{ Mann-Whitney Test } \\
\hline \multicolumn{2}{|c|}{ I\&II } & \multicolumn{2}{|l|}{ I\&III } & \multicolumn{2}{|c|}{ II\&III } \\
\hline \multicolumn{2}{|c|}{$<0.001 *$} & \multicolumn{2}{|l|}{$<0.001 *$} & \multicolumn{2}{|c|}{$<0.001 *$} \\
\hline
\end{tabular}

There was significant positive correlation between 24P3 and Prothrombin in group I.

Table (8): Correlations

\begin{tabular}{|c|c|c|c|}
\hline \multirow{2}{*}{ Groups } & & \multicolumn{2}{|c|}{$24 P 3$} \\
\hline & & $r$ & P-value \\
\hline \multirow{13}{*}{ Group I } & AFP & 0.839 & 0.114 \\
\hline & Age & -0.866 & 0.268 \\
\hline & RBCs & -0.917 & 0.840 \\
\hline & WBCs & -0.482 & 0.760 \\
\hline & Hb & -0.828 & 0.367 \\
\hline & Albumin & -0.911 & 0.353 \\
\hline & TotalBilirubin & 0.889 & 0.318 \\
\hline & DirectBilirubin & 0.877 & 0.808 \\
\hline & AST & 0.908 & 0.407 \\
\hline & ALT & 0.896 & 0.532 \\
\hline & Prothrombin & 0.840 & $0.028 *$ \\
\hline & Platelet & 0.264 & 0.260 \\
\hline & HCV-RNA & -0.309 & 0.185 \\
\hline \multirow{13}{*}{ Group II } & AFP & 0.706 & 0.276 \\
\hline & Age & -0.077 & 0.686 \\
\hline & RBCs & -0.048 & 0.802 \\
\hline & WBCs & -0.460 & 0.110 \\
\hline & Hb & -0.405 & 0.264 \\
\hline & Albumin & -0.466 & 0.903 \\
\hline & Total Bilirubin & 0.286 & 0.126 \\
\hline & Direct Bilirubin & 0.337 & 0.069 \\
\hline & AST & 0.415 & 0.230 \\
\hline & ALT & 0.444 & 0.140 \\
\hline & Prothrombin & 0.402 & 0.280 \\
\hline & Platelet & -0.291 & 0.213 \\
\hline & HCV-RNA & -0.027 & 0.909 \\
\hline
\end{tabular}

The cut off for $24 \mathrm{P} 3$ is $>250 \mathrm{ng} / \mathrm{mL}$ while for AFP it is $>200 \mathrm{Iu} / \mathrm{L}$.

24P3's sensitivity, specificity, PPV, NPV and accuracy were all $100 \%$ while AFP's sensitivity is
$70 \%$, specificity is $85 \%$, PPV $90 \%$, NPV $65 \%$ and accuracy $78 \%$.

Table (9): The cut off, Sensitivity, specificity, PPV, NPV and accuracy calculated for 24P3 and AFP.

\begin{tabular}{|l|c|c|c|c|c|c|}
\hline & $\begin{array}{c}\text { Cut } \\
\text { off }\end{array}$ & Sens. & Spec. & PPV & NPV & Accuracy \\
\hline $24 P 3$ & $>250$ & $100 \%$ & $100 \%$ & $100 \%$ & $100 \%$ & $100 \%$ \\
\hline AFP & $>20$ & $70 \%$ & $\mathbf{8 5 \%}$ & $\mathbf{9 0 \%}$ & $\mathbf{6 5 \%}$ & $\mathbf{7 8 \%}$ \\
\hline
\end{tabular}

\section{DISCUSSION}

HCV infection is of global importance affecting all countries, leading to a major global health problem that requires wide spread active interventions for its prevention and control. Chronic hepatitis $\mathrm{C}$ is linked to the development of cirrhosis and hepatocellular carcinoma in many areas of the world ${ }^{(8)}$.

AFP is the most widely used tumor biomarker currently available for the early detection of HCC. Findings of a previous clinical study by YanJieetal. $^{(9)}$ demonstrated that serum AFP has a sensitivity of $41-65 \%$ and specificity of $80-94 \%$ when the cut-off valueis $20 \mathrm{ng} / \mathrm{ml}$.

Due to AFP limitations in accurate early diagnosis of HCC and prognosis of chronic liver disease, other alternatives have to be considered. 24P3 has been suggested as a key player in different cancer types. Its oncogenic effect may be related to the complex 24P3/MMP-9 ${ }^{(6)}$.

The present study included 60 patients who were divided into 3 groups $\mathrm{HCC}$ (groupI), HCV (groupII) and control (group III).

This study showed that there is significantly decrease in WBCs count in HCC patients. Our findings were in agreement with those of Alan Franciscus $^{(10)}$ and Lustberg ${ }^{(11)}$ who found out that Neutropenia is a common side effect of interferonbased therapy. Clinical studies have shown that most people on $\mathrm{HCV}$ treatment experience some reduction in neutrophil count below the normal range.

Another study stated that $\mathrm{HCV}$ infected patients have normal level of WBCs in their peripheral blood which may be attributed to the fact that all patients were recently diagnosed with $\mathrm{HCV}$ and that the main cause of neutropenia in $\mathrm{HCV}$ patients is the treatment they receive to eradicate the virus $^{(\mathbf{1 2})}$.

The present study showed that $\mathrm{Hb}$ mean values are $\quad(9.25 \pm 1.9 \mathrm{~g} / \mathrm{dL}), \quad(12.35 \pm 1.9 \mathrm{~g} / \mathrm{dL}) \quad$ and $(13.45 \pm 2.0 \mathrm{~g} / \mathrm{dL})$ in $\mathrm{HCC}, \mathrm{HCV}$ and control group respectively (Table:1). There is a statistical significant difference in $\mathrm{Hb}$ among the three groups. Values for $\mathrm{Hb}$ in HCV patients are almost normal but showed a decrease in HCC patients.

There is no decrease in hemoglobin level in $\mathrm{HCV}$ group. Our findings were in agreement with those of ElHefnia et al. ${ }^{(13)}$ who concluded that patients who had higher hemogloblin and hematocrit 
levels are HCV infected patients and this attributed to increased production of erythropoietin from HCVinfected patient's hepatocyte.

Finkelmeier et al. ${ }^{(14)}$ found out that anemia is a common complication in several types of cancer including hepatocellular carcinoma (HCC) and this was in agreement with the present study.

In present study, platelets mean values are $\left(70 \pm 28 \times 10^{3} / \mathrm{uL}\right), \quad\left(106 \pm 40 \times 10^{3} / \mathrm{uL}\right) \quad$ and $\left(275 \pm 148 \times 10^{3} / \mathrm{uL}\right)$ in $\mathrm{HCC}, \mathrm{HCV}$ and control group respectively (Table:5-6). There is a statistical significant difference in platelets count among the three groups. This study showed that there is significantly decrease in PLTs count in HCC patients.

HCC and HCV group showed thrombocytopenia which is the most common hematological abnormality in patients with $\mathrm{HCV}$ infection ${ }^{(15)}$.

The pathophysiology of thrombocytopenia in patients with $\mathrm{HCV}$ is complex and involves the interaction of multiple factors. These factors may be grouped into disease-related factors and treatmentrelated factors. Factors related to the disease include hepatic fibrosis or cirrhosis, hyperspleenism, bone marrow suppression, immune dysfunction and decreased thrombopoietin levels or activity ${ }^{(\mathbf{1 6})}$.

These results showed that there is a statistical significant increase in ALT and AST levels above normal value in $\mathrm{HCC}$ and $\mathrm{HCV}$ groups.

In previous studies, there was persistent elevated ALT levels in Egyptian adults infected with $\mathrm{HCV}^{(\mathbf{1 7 )}}$ and this is in agreement with the present study.

However, another study concluded that patients with chronic HCV infection had normal or borderline ALT values ${ }^{(\mathbf{1 8 )}}$.

In astudy done by Wuetal (19), HCV infected patients showed that elevated ALT levels above $70 \mathrm{u} / \mathrm{L}$ is strongly associated with the incidence of HCC.

In the present study, Total Bilirubin mean values are $(8.6 \pm 1.979 \mathrm{mg} / \mathrm{dl}),(3.76 \pm 1.64 \mathrm{mg} / \mathrm{dL})$ and $(0.8 \pm 0.42 \mathrm{mg} / \mathrm{dL})$ in $\mathrm{HCC}, \mathrm{HCV}$ and control group respectively.

There is astatistical significant difference in Total Bilirubin among the three groups. Bilirubin is significantly higher in HCC and HCV groups above normal value.

Aprevious study stated that bilirubin levels may be elevated in HCV patients and when its level is higher than $30 \mathrm{mg} / \mathrm{dl}$ that indicate more severe disease $^{(\mathbf{2 0 )}}$. This is in agreement with the present study.

While another study performed on 2416 HCC patients showed that most patients (1443 patients) had abilirubin level less than $1.5 \mathrm{mg} / \mathrm{dl}$ and rest of patients (973) had abilirubin level more than $1.5 \mathrm{mg} / \mathrm{dl}^{(21)}$.
In present study, Albumin mean values are $(2.8 \pm 0.283 \mathrm{~g} / \mathrm{dL}), \quad(3.45 \pm 0.7 \mathrm{~g} / \mathrm{dL}) \quad$ and $(4.3 \pm 0.85 \mathrm{~g} / \mathrm{dL})$ in $\mathrm{HCC}$, HCV and control group respectively.

There is astatistical significant difference in albumin levels among the three groups. Serum albumin level is significantly lower in HCC and $\mathrm{HCV}$ patients below normal value.

The results done by Carrand Guerra ${ }^{(22)}$ indicate that low serum albumin levels correlate with increased parameter measures of HCC aggressiveness, In addition to their role as amonitor of systemic inflammation and that correlates with the present study.

While a previous study reported that in studying of 454 patients with HCV, only 25 showed low albumin level and rest of patients had normal albumin level ${ }^{(23)}$.

It should be noted that low serum albumin concentration indicates poor liver function and that takes several weeks of impaired albumin production until the serum albumin level drops ${ }^{(23)}$. This might explain why our results contradicted that of this study.

In present study prothrombin time (PT) mean values are $(23.45 \pm 5.02 \mathrm{~second}),(15.75 \pm 4.7 \mathrm{sec})$ and $(12.2 \pm 1.41 \mathrm{sec})$ in $\mathrm{HCC}, \mathrm{HCV}$ and control group respectively.

There is a statistical significant difference in PT between the three groups. PT is significantly prolonged in HCC and HCV groups.

In hepatitis $\mathrm{C}$ virus infection, a prolonged PT was observed in Leticia etal. $^{(24)}$ study which maintained that the prolongation in the clotting time correlates with the degree of deficiency or inhibition of extrinsic or common pathway, hence the degree of liver damage. This is in agreement with the present study.

Wang et al. ${ }^{(25)}$ reported that PT is the independent risk factor for HCC prognosis. It was found out that in advanced HCC pathological stage, the coagulation parameters were more impaired and patients with advanced HCC exhibited prolonged PT levels.

This correlates with a previous study which reported that the risk of HCC development was higher in subjects with high viral load of HCV-RNA than subjects with low viral load ${ }^{(26)}$.

In the present study, AFP median values are $(1715 \mathrm{IU} / \mathrm{mL}),(123.75 \mathrm{IU} / \mathrm{mL})$ and $(2.7 \mathrm{IU} / \mathrm{mL})$ in $\mathrm{HCC}, \mathrm{HCV}$ and control group respectively.

There is statistical significant difference in AFP among the three groups. AFP is significantly higher in HCC group.

A previous study showed that large proportion of hepatocellular carcinoma (HCC) patients do not secrete elevated levels of the tumor marker alphafeto protein (AFP). It found 413 biopsy-proven 
unresectable HCC patients with low serum AFP values $^{(27)}$.

While another study done by Balogh et al. ${ }^{(28)}$ found out that AFP $>400-500 \mathrm{ng} / \mathrm{ml}$ is considered diagnostic for HCC, although fewer than half of patients may generate levels that high. With values of that magnitude, the specificity of AFP is close to $100 \%$ but at acost to the sensitivity which falls below $45 \%$. The positive predictive value (PPV) of AFP is low, ranging from $9 \%$ to $32 \%$.

The role of AFP in the diagnosis and surveillance of HCC is getting smaller owing to the advances in imaging modalities ${ }^{(29)}$.

The Cut off, sensitivity, specificity, PPV, NPV and accuracy were calculated for AFP. Cut off for AFP was > 20ng/ml, sensitivity was $70 \%$, specificity was $85 \%$, PPV $90 \%$, NPV $65 \%$ and accuracy was $78 \%$

This agrees with a previous study which reported that AFP sensitivity was $76 \%$, specificity was $88 \%$, PPV $88.9 \%$, NPV $62.65 \%$, and accuracy $82 \%$ (5).

In present study $24 \mathrm{P} 3$ median values are $(424.85 \mathrm{ng} / \mathrm{ml}),(166.86 \mathrm{ng} / \mathrm{ml})$ and $(47.69 \mathrm{ng} / \mathrm{ml})$ in HCC, HCV and control group respectively

There is statistical significant difference in $24 \mathrm{P} 3$ levels among the three groups. 24P3 levels is significantly higher in HCC and HCV groups as compared to healthy control.

$24 \mathrm{P} 3$ is suggested to be emerging as a novel predictive biomarker not only in liver cancer but also in other fields ${ }^{(30)}$.

In a study conducted by which carried out in patients with chronic hepatitis C (CHC), 24P3 levels were found to be increased, and it has been suggested as a marker of fibrosis.

The tumors showing high 24P3 expression (expression levels greater than the $75^{\text {th }}$ percentile of normal samples) were: ovarian $(91.2 \%)$, thyroid (83.7\%), liver $(68.8 \%)$, colon $(66.3 \%)$, kidney $(64.7 \%)$, lung $(63.1 \%)$, pancreas $(60.2 \%)$ and bladder $(50.5 \%)^{(31)}$.

While, the percentages of tumor cases showing $24 \mathrm{P} 3$ transcripts below the $25^{\text {th }}$ percentile of "normal" values were almost $100 \%$ of all hematological malignancies and $94.6 \%$ of head and neck cancer, $71.4 \%$ of esophagus cancer and $59.4 \%$ of cervical carcinoma. These data suggest that 24P3 is a candidate marker for tumor growth in a fraction of solid tumor and a favorable prognostic factor for the remaining cancer types showing lower levels of 24P3 transcript levels ${ }^{(32)}$.

A previous study stated that serum $24 \mathrm{P} 3$ could serve as a valuable biomarker of early stage hepatic damage and that the measurement of 24P3 in urinary samples could be useful to predict the outcome of cirrhosis, liver transplantation rejection, and hepatic fibrosis ${ }^{(33)}$. This is in agreement with present study.
The cut off for $24 \mathrm{P} 3$ is $>250 \mathrm{ng} / \mathrm{mL}$. 24P3's sensitivity, specificity, PPV, NPV, and accuracy were all $100 \%$.

In a study done by Abd El Moety et al. ${ }^{(5)}$, 24P3 had 100\% sensitivity, specificity, PPV, NPV, and accuracy and therefore they concluded that it can be used as a future diagnostic marker with better sensitivity and specificity for the progression of hepatocelluar carcinoma. This is in agreement with the present study.

Recently, association of $24 \mathrm{P} 3$ and $24 \mathrm{P} 3-2 \mathrm{R}$ expression with conventional clinicopathological HCC parameters was studied. The study showed that the expression of both genes was correlated and upregulated in HCC tissue and associated with vascular invasion status and TNM classification stage of malignant tumors. In addition, the expression of both genes correlated well with tumor recurrence, poor prognosis, and overall survival rates suggesting that 24P3 and 24P3-2R expression are suitable prognostic factors and potential therapeutic targets in $\mathrm{HCC}^{(3)}$.

\section{CONCLUSION}

Serum 24P3 levels in patients with HCV may be used as a guide for progression and prognosis of HCC. In these patients, if 24P3 levels were found to be high, serum alpha- feto protein and ultrasonographic examination could be repeated at more frequent intervals. This may also used as a guide in terms of the treatment plan. Measurement of 24P3 in sera of large number of patients and follow up may pave the way to pick up early stage of HCC and showed its prognostic effect.

\section{RECOMMENDATIONS}

- Measurement of 24P3 in a large scale of HCC patients to explore its prognostic value.

- Correlate 24P3 with other biomarkers of biological value in HCV/HCC eg: MMP-9.

- $24 \mathrm{P} 3$ can be used as a therapeutic target in HCC patients in the future.

- $24 \mathrm{P} 3$ can be used for screening of HCV patients for HCC development.

\section{REFERENCES}

1. Pegah G, Sofie F,Munkhzul O et al. (2017): Mortality assessment of patients with hepatocellular carcinoma according to underlying disease and treatment modalities. Journal list Medicine (Baltimore), 96(9): e5904.

2. Hyunsoo K, JiYoung P, Yong K, Areum S, Injun Y, Su Y, Jung Y, Taesung P,Youngsoo K (2017): Serum fibronectin distinguishes the early stages of hepatocellular carcinoma. Scientific Reports, 7: 9449.

3. Asimakopoulou $A$, Weiskirchen $\mathbf{S}$ and Weiskirchen $\mathbf{R}$ (2016): Lipocalin 2 (LCN2) Expression in Hepatic Malfunction and Therapy. Front. Physiol., 7:430.

4. Boekhorst B, Bovens S, Hellings W et al. (2011): Molecular MRI of murine atherosclerotic plaque 
targeting NGAL: a protein associated with unstable human plaque characteristics. Cardiovasc Res., 89: 680-688.

5. Abd El Moety H, El Sharkawy R and Hussein N (2013): Lipocalin: A Novel Diagnostic Marker for Hepatocellular Carcinoma in Chronic Liver Disease Patients in Egypt. International Journal of Clinical Medicine, 4: 440-450.

6. Lin C, seng T and Yang I (2012): Role of lipocalin 2 and its complex with matrix metalloproteinase-9 in oral cancer. Oral Diseases, 18: 734-740.

7. Marina B and Schuppan D (2013): Progression of Liver Fibrosis in Post-Transplant Hepatitis C: Mechanism, Assessment and Treatment. Journal of Hepatology, 58(5): 1028-1041.

8. Lavanchy $\mathbf{D}(\mathbf{2 0 1 1})$ : Evolving epidemiology of hepatitis C virus. Clin Microbiol Infect., 17 (2): 107-15.

9. Yan Z, Qiang J and Guan L (2013): Tumor markers for hepatocellular carcinoma. Molecular And Clinical Oncology, 1: 593-598.

10. Alan F (2013): HCV treatment-side effect management. Hepatitis C Support Project, 6:95813

11. Lustberg $M$ (2012): Management of Neutropenia in Cancer Patients. Clin Adv Hematol Oncol., 10 (12): 825-826.

12. Streiff B, Mehta S and Thomas L (2002): Peripheral blood count abnormalities among patients with hepatitis C in the United States. Hepatology,35(4):947952.

13. Ashraf M, Reda A and Ebianc H (2015): Iron status and erythropoiesis in chronic hepatitis $\mathrm{C}$ patients on hemodialysis. The Egyptian Society of Haematology,40 (2): 80-84.

14. Finkelmeier F, Bettinger D, Köberle V et al. (2014): Single measurement of hemoglobin predicts outcome of HCC patients.Medical Oncology, 31(1):806.

15. Franco A, Corken A and Ware $H$ (2015): Platelets at the interface of thrombosis, inflammation, and cancer. Blood, 126(5): 582-588.

16. Oscar M, David F, Diako M et al. (2016): The pathophysiology of thrombocytopenia in chronic liver disease. Hepatic Midicine, 8:39-50.

17. Abed T, Elfeky A, Fouda E et al. (2016): Prevalence and risk factors of asymptomatic hepatitis $\mathrm{C}$ virus infection among a sample of school aged Egyptian children. International Journal of Medical and Health Sciences ,5 (2)87-93.

18. Michael F (2008): Hepatitis C Infection with Normal Liver Chemistry Tests. Clin Gastroenterol Hepatol., 6(5): 503-505.

19. Du P, Wu L, Wu X et al. (2015): A systematic analysis of human lipocalin family and its expression in esophageal carcinoma. Scientific Reports,5: 12010.

20. Naga S (2017): Viral Hepatitis Work up. https://emedicine.medscape.com.

21. Carr B, Guerra V, Giannini $G$ et al. (2014): Association of abnormal plasma bilirubin with aggressive HCC Phenotype. Semin Oncol.,41(2): 252258.

22. Carr B and Guerra V (2017): Serum albumin levels in relation to tumor parameters in hepatocellular carcinoma patients.Int J Biol Markers, 32(4):391-396.

23. Nagao $Y$ and Sata $M$ (2010): Serum albumin and mortality risk in a hyperendemic area of HCV infection in Japan Nagao and Sata Virology Journal, 7: 375.

24. Leticia I, Obeagu I, Andrew A et al. (2014): The Effect of Viral Hepatitis ON APTT, PT, TT, Fibrinogen and Platelet among Blood Donors at FMC, Umuahia. OSR Journal of Dental and Medical Sciences, 13(8):57-63.

25. Xue W, Min M, Zhong $H$ et al. (2017): A retrospective discussion of the prognostic value of combining prothrombin time (PT) and fibrinogen $(\mathrm{Fbg})$ in patients with Hepatocellular carcinoma.J Cancer, 8(11): 20792087.

26. Noh R, Lee H, Kwon W et al. (2016): Clinical impact of viral load on the development of hepatocellular carcinoma and liver-related mortality in patients with hepatitis $\mathrm{C}$ virus infection. https://www.hindawi.com/journals/grp/2016/7476231/ abs/

27. Carr B, Pancoska P, and Robert R (2010): Low alphafetoprotein hepatocellular carcinoma.Journal of Gastroenterology and Hepatology, 25(9):1440-1746.

28. Balogh J, Victor D, Asham H et al. (2016): Hepatocellular carcinoma: a review. J Hepatocell Carcinoma,3: 41-53.

29. Fitzmorris $P$ and Singal A (2015): Surveillance and Diagnosis of Hepatocellular Carcinoma. Gastroenterol Hepatol (N Y), 11(1): 38-46.

30. Malyszko J, Lukaszyk E, Glowinska I et al. (2015): Biomarkers of delayed graft function as a form of acute kidney injury in kidney transplantation. Scientific Reports, 5: 11684.

31. Candido S, Maestro R, Polesel J et al. (2014): Roles of neutrophil gelatinase-associated lipocalin (NGAL) in human cancer. Oncotarget.,5(6): 1576-1594.

32. Danaher P, Warren S, Dennis L et al. (2017): Gene expression markers of Tumor Infiltrating Leukocytes. Journal for Immuno Therapy of Cancer , 5:18.

33. Ariza X, Graupera I, Coll M et al. (2016): Neutrophil gelatinase associated lipocalin is a biomarker of acute and chronic liver failure and prognosis in cirrhosis. J.Hepatol., 65: 57-65. 